\author{
Л.Л. Касаткин \\ Институт русского языка им. В. В. Виноградова РАН \\ (Россия, Москва) \\ rolekas@yandex.ru
}

\title{
НЕКОТОРЫЕ ЗАКОНОМЕРНОСТИ ПРОЦЕССА СМЕНЫ МЕСТА УДАРЕНИЯ В СЛОВАХ РУССКОГО ЯЗЫКА
}

В статье рассматриваются особенности процесса смены места ударения в формах мн. ч. косв. падежей существительного «камень», род. и дат. п. ед. ч с предлогами существительного «утро», 2-е и 3-е л. наст. вр. глагола «идти». В качестве иллюстрации используются поэтические произведения XVIII-XIX вв., приведенные в Национальном корпусе русского языка: стихотворения В.А. Жуковского, Г. Р. Державина, А. С. Пушкина, М. Ю. Лермонтова, А. А. Фета, И. А. Бунина, А. А. Блока, Н. С. Гумилева, К. Д. Бальмонта, А. А. Ахматовой, М. И. Цветаевой и др.

Отмечается особенность процесса смены места ударения: при колебании места ударения: ударение на окончании чаще встречается в конце стихотворной строки. Помимо этого, для части примеров выделяется и позиция в начале строки, где, как и в конце строки, процесс смены места ударения идет наиболее интенсивно.

Эти наблюдения позволяют предположить, что, во-первых, проявлению данного языкового процесса способствует сильная фразовая позиция, так как начало и конец строки обычно совпадают с началом и концом фразы, и они привлекают особое внимание говорящих. Кроме того, играет роль и качество гласных, с которых и на которые переносится ударение: более длительный гласный (среднего или нижнего подъема) способствует «перетягиванию» на себя ударения с гласного верхнего подъема, что невозможно в случае, если гласные в данной форме слова одного подъема (и одинаковой собственной длительности).

Ключевые слова: русское литературное произношение, ударение, смена места ударения

У многих слов русского языка в настоящее время или в прошлом место ударения варьируется во всех или в некоторых формах. Это варьирование отражает процесс смены места ударения в данном слове, идущий или прошедший в русском языке. Поэтические произведения помогают увидеть некоторые закономерности этого процесса.

У слова камень, как отмечает Н.А. Еськова, в XVIII-XIX вв. «варианты ка́мней, ка́мням, ка́мнями, ка́мнях употреблялись чрезвычайно широко»; представлены 
у многих авторов. «Эти варианты ударения сохраняются в поэтической традиции XX века» [Еськова 2008: 111]. Хотя нормой современного русского языка считается ударение на окончании в этих формах [Каленчук и др. 2012: 282; Еськова 2015: 305].

Национальный корпус русского языка (НКРЯ, [www.ruscorpora.ru]) приводит в поэтическом подкорпусе примеры употребления форм косвенных падежей мн. числа: камней - 657 примеров, камням - 226, камнями - 139, камнях - 196, всего 1218 примеров. Соотношение этих форм с ударением на корне и на окончании в XVIII-XIX вв. 268:81 $=77: 23 \%$, а в XX в. 135:734 = 16:84\%. Но еще нагляднее процесс смены ударения на корне на ударение на окончании в этих формах виден на примере разных поэтов.

В.А. Жуковский представлен в НКРЯ 36 примерами этих форм, во всех ударение на корне. Вот некоторые:

Уж никому не будут продавать

Ни золота, ни серебра, ни перлов,

Ни ка́мней дорогих, ни риз пурпурных.

<Первое переложение Апокалипсиса>, 1851-1852

И спутнику он скажет: «В старину

Стоял там Базель; эта груда ка́мней

В то время церковью Петра была...»

Тленность, 1818

Лучи бросаются златыми полосами,

Горят на белизне разрушенных столпов,

И пеной огненной с кипящими волнами

По ка́мням прядают и гаснут на лету.

«От вашего величества давно...», 1819

Дивишься, странник,

Ты этим ка́мням?

Подобных много

Близ хижины моей.

Путешественник и поселянка, 1819

В тени шиповников зеленых,

Под ка́мнями, под прахом

Лежат они и ветер

Травой над ними шевелит.

Путешественник и поселянка, 1819

И серна, прискакав на шумный в ка́мнях ключ, Недвижно, робкая, журчанью струй внимает... Песнь барда..., 1806 
Ты скажешь: смерть сидит на этих ка́мнях.

А домик наш?.. Взгляни: как будто церковь,

Светлеет на холме, и окна блещут.

Тленность, 1818

В поэтических произведениях А.С. Пушкина, по данным НКРЯ, встречается 9 этих форм, во всех ударение на корне.

Близ ка́мней вековых, покрытых желтым мохом

Проходит селянин с молитвой и со вздохом...

Когда за городом, задумчив, я брожу... 1836

Однажды темною порою,

По ка́мням берегом крутым

Наш витязь ехал над рекою...

Руслан и Людмила, 1820

В пустыне / Пробился ключ,

Обложен ка́мнями простыми.

В пустыне, 1830

Стихи М. Ю. Лермонтова отражают начавшийся процесс смены места ударения в этих формах слова камень. Лермонтов представлен в НКРЯ тридцатью примерами, из них 13 с ударением на корне и 17 - на окончании.

Налево - пропасть; по краям

Ряд красных ка́мней, здесь и там

Всегда обрушиться готовый.

Измаил-Бей, 1832

И там, когда вечерняя заря

Бледнеющим румянцем одевает

Вершины гор, - пустынная змея

Из-под камне́й резвяся выползает...

Аул Бастунджи, 1832-1833

Змея скользила меж камне́й;

Но страх не сжал души моей:

Я сам, как зверь, был чужд людей

И полз и прятался, как змей.

Мusılpu, 1839

По ка́мням прыгали, шумели

Ключи студеною волной...

Демон: Восточная повесть, 1841 
По камня́м струится Терек,

Плещет мутный вал... Казачья колыбельная песня, 1838

Так юный воин говорил, И влажный взор его бродил По диким соснам и камня́м И по туманным небесам.

Последний сын вольности, 1831

Важная особенность этого процесса смены места ударения - ударение на окончании чаще встречается в конще стихотворной строки. Так, в стихах Лермонтова 8 подобных форм в конце строки, во всех случаях ударение на окончании.

Разные поэты по-разному отражают этот процесс. Так, в НКРЯ у А.Н. Майкова отмечено 20 примеров таких форм, из них 18 с ударением на корне, в том числе 8 в конце строки, и 2 с ударением на окончании в середине строки.

И грот таинственный, откуда струйка вод

Меж ка́мней падает, звенит и брызги бьет...

«Всё думу тайную в душе моей питает...», 1840

В могилах тебя отыскали средь пепла и ка́мней;

Художник сложил воедино разбитые члены,

Трудяся с любовью, как будто бы складывал вместе

Куски драгоценные писем от милой...

Антики, 1843

Пред солнцем гребень гор снимает свой покров,

Спешит свершить намаз свой нива золотая,

И шелохнулся лес, с кудрей своих роняя,

Как с ханских четок, дождь камне́й и жемчугов...

Алушта днем, 1869

Загремело и загрохотало

Вдруг по темным адским подземельям,

Как влетел в него огнедышащий

И скакал по ка́мням конь Одинов.

Бальдур, 1870

Добрый конь идет не оступаясь

По корням древесным и по ка́мням,

Для него привычен путь пустынный...

Бальдур, 1870 
Ставь перед нами из глины кувшины простые

С влагой студеной, почерпнутой в полдень палящий

В этом ручье, что так звонко меж ка́мнями льется...

Пустьннику, 1840

Вдруг у ваших ног блеснет

И, как ящерица в ка́мнях,

Шаловливо пропадет.

«Мисс! не бойтесь легкой шутки...», 1858-1859

У В.Я. Брюсова 53 примера, из них 36 с ударением на корне, в том числе 2 в конце строки, 17 с ударением на окончании, в том числе 10 в конце строки.

Так стройте призрак жизни новой

Из старых ка́мней давних стен.

«Современность грохочет, грозит, негодует...», 1920

Здесь, в стране исканий,

Где века грохочут листвой,

Мысли гениев - реки, и с ка́мней -

В непостижность водопад роковой...

«Вот я-обвязан, окован...», 1924

Клонит лик пред сыном Афродита,

Эрос-Мститель гнет священный лук.

Пропасть высшей страсти нам открыта.

Чу! на дне - камне́й скользнувших звук!

Цезарь Клеопатре, 1920

И женщина, смеясь, недвижно стала,

Среди высоких илистых камне́й,

И, молча, подойти мне указала.

Приблизился я, как лунатик, к ней...

Лесная дева, 1902

Иль другие вспомни были,

Как со всех концов земли

К этим ка́мням подходили,

В пестрых флагах, корабли!

Разговор, 1916

Буйство потока в горах стремится по вымытым ка́мням.

О приближении веснь, 1907 
И лишь дрожат листвою апельсины, И лишь волна дробится по камня́м. «Торжественно-больное беспокойство...», 1895

Ходят и дерзко поводят плечами,

Ка́мнями, тканями, телом блестя, Бедрами, шелком шурша, шелестя... В публичном доме, 1905

И, как камня́ми-невеличками

Осыпан в перстне бриллиант, В корзине желтыми лисичками Я выстилаю узкий кант. По грибы, 1916

Небо чернело с огнями, Море чернело без звезд. Плотно обложен камня́ми

Был изогнутый объезд. «Небо чернело с огнями...», 1899

А за гранями обрывов Волн восторженный разбег, И на ка́мнях, вдоль заливов, Пена, чистая, как снег. На Готланде, 1906

Жрецы богов, надменны и жестоки, Считали в храмах груды серебра И на камня́х свои чертили строки; «И в то же утро солнце пронизало...», 1903

Другие, покорно, на острых камня́х Лежат и грызут иссохшие руки, Как на прахе брошенный прах... В пустынях, 1911

У М.А. Волошина 21 пример, из них 7 с ударением на корне (только в середине строки) и 14 с ударением на окончании. У А. А. Блока 13 примеров, из них 5 с ударением на корне в середине строки и 8 на окончании. У И.А. Бунина 22 примера, из них 4 с ударением на корне в середине строки и 18 на окончании. У К.Д. Бальмонта 13 примеров, из них 1 с ударением на корне в середине строки и 12 на окончании. У Н.С. Гумилева 15 примеров, из них 1 с ударением на корне в середине строки 
и 14 с ударением на окончании. У В.И. Иванова 13 примеров, из них 1 с ударением на корне в середине строки и 12 с ударением на окончании. У Саши Черного 13 примеров, все с ударением на окончании. У М.И. Цветаевой 12 примеров, все с ударением на окончании.

У слова утро в формах род. и дат. падежей ед. числа с предлогами в XVIII$\mathrm{XX}$ вв. прошёл процесс переноса ударения с корня на окончание: $c$, до, от ýmpa > c, до, от утра́, к, по ýmру > к, по утри́ [Воронцова 1979: 129-131]. И здесь то же различие: ударение на корне в примерах в начале и середине стихотворной строки и единично в конце строки, ударение на окончании - в начале, в середине и в конце строки.

НКРЯ приводит 664 примера с утра, из них 13 примеров с ударением на корне c ýmpa во временном значении, все в начале и середине строки. Примеры с ударением на окончании с утра́ во всех положениях в строке - в начале, в середине и в конце.

Соловей не умолкает,

Свищет с у́тра до утра́;

Другу милому, он знает,

Петь одна в году пора.

И. И. Дмитриев. «Пой, скачи, кружись, Параша!..» (1795)

От фиалок синеглазых

Небом кажется земля,

С у́тра до́ ночи над розой

Рвется сердце соловья.

М. И. Цветаева. Этери (1940)

С утра́ до вечера держася на карете,

Мне тряско рассуждать о боге и о свете;

Д. И. Фонвизин. Послание к слугам... (1788)

А для мужчин в буфете было

Еще с утра́ принесено

В больших трех ящиках вино.

М. Ю. Лермонтов. Тамбовская казначейша (1838)

Она, как втершийся с утра́

Заимодавец терпеливый,

Торча в передней молчаливой,

Не трогалась с ковра.

А. С. Пушикин. На выздоровление Лукулла (1835) 
Кроме того, 5 примеров, где у ýmра есть зависимые слова, и в таких конструкциях переноса ударения с корня на окончание не происходило. В частности:

С у́тра дней счастлив и славен,

Кто тебе, мой мальчик, равен?

Е. А. Баратынский. «Здравствуй, отрок сладкогласной!..» (1841)

Спеет дружная работа:

С у́тра раннего до ночи

Сто работников послушных

Носят камни, возят бревна...

П. П. Ериов. Сузге (1837)

В НКРЯ приведен 541 пример с сочетанием до утра, из них 62 примера во временно́м значении с ударением на корне в начале и середине строки и 1 пример в конце строки. Примеры с ударением на окончании до утра́ во всех положениях в строке - в начале, в середине и в конце. В частности:

Проснется за́ полдень, и снова

До у́тра жизнь его готова,

Однообразна и пестра.

А. С. Пушкин. Евгений Онегин (1823-1824)

Но ты останься здесь и больше не тужи, И просьбу такову до у́тра отложи...

В. И. Майков. Елисей, или Раздраженный Вакх (1769)

Теперь твой слух не ранит

Неистовая речь,

Теперь никто не станет

Свечу до у́тра жечь.

A. А. Ахматова. «Чугунная ограда...» (1921)

Что-то он не пишет

С стороны чужой!

Видно, всё не время,

Много всё забот...

А вот мне до у́тра

Сон на ум нейдёт.

Н. П. Огарев. Разлука (1858)

Я прохожий — и от снега

До утра́ ищу ночлега...

А. А. Фет. Метель (1847) 
Вчера к развалинам, вдоль этого ущелья,

Скакали всадники - и были зажжены

Костры - и до утра́ был слышен гул веселья -

Пальба, и барабан, и вой зурны.

Я. П. Полонский. После праздника (1849)

Как сладко слышать у шатра

Вечерней пушки гул далекий

И погрузиться до утра́

Под теплой буркой в сон глубокий...

К. Н. Батюшков. К Никите (1817)

Кроме того 6 примеров, где у ýmра есть зависимые слова, в частности:

Пусть ярок трепет искры зримой,

Но он лишь миг владеет тьмой,

Где человек - как сев озимый,

До у́тра майского немой!

Ю. К. Балтрушайтис. Раздумье (1913)

Но до у́тра серого

у сырого дерева,

темного, сторукого,

плакала старуха...

С. И. Кирсанов. Песня о железнодорожнике (1927)

Пока твой сон - сон девичий -

Спокоен, тих до у́тра дня,

Как раз беду наслушаешь:

В цвету краса загубится,

Лицо твое румяное

Скорей платка износится.

А. В. Кольцуов. Пора любви (1837)

В сочетании от утра - 34 примера, с ударением на корне от у́mра 12 примеров в начале и в середине строки, в конце строки нет. Примеры с ударением на окончании om ympá во всех положениях в строке - в начале, в середине и в конце. В частности:

И всем из Твоего пера

Блаженство смертным проливаешь;

Подобно в карты не играешь,

Как я, от у́тра до утра́.

Г. Р. Державин. Фелица (1782) 
На тройке пренесенный

Из родины смиренной

В великой град Петра,

От у́тра до утра́

Два года всё кружился...

А. С. Пушкин. Городок (1814-1815)

Уж полпути от у́тра до полудня

Светило дня неспешно протекло.

М. А. Кузмин. Всадник (1908)

От утра́ и от полудня

Под поющий в небе гром,

Словно ведра, наши будни

Он наполнит молоком.

C. А. Есенин. Преображение (1917)

Что ты монахиней живешь

И только от утра́ до вечера поешь?

A. Е. Измайлов. Горлица и малиновка (1813)

Дажбогова сестра,

Пока он на небе, я гуслям сладкострунным

$\mathrm{B}$ чертогах матери внимаю от утра́

До ночи сумрака.

А. А. Кондратьев. Дзевана (1910-1936)

Кроме того 1 пример с зависимым словом - определением и 1 в значении указания на предмет как источник, причину состояния природы.

Поля покрылися пушистыми снегами,

И солнце, скрытое туманными зыбями,

Как будто крадется невидимой стезей

От у́тра позднего до ранней тьмы ночной.

A. С. Хомяков. Зима (1830)

Не хочешь отдыха и ночлега,

А только - шагать вдоль тишины,

Покуда бело не от солнца - от снега,

Светло не от у́тра - светло от луны.

Б. А. Слуц̧кий. В сорок лет (1961)

В сочетании к утру 145 примеров, с ударением на корне к ýmру 68 примеров в начале и в середине строки и 1 пример в конце строки. Примеры с ударением 
на окончании к утру́ во всех положениях в строке - в начале, в середине и в конце. В частности:

К у́тру я горе твое успокою,

Сладкие грезы его усыпят,

Будешь ты так же пригожа собою,

Только красивее дам я наряд...

Н. А. Некрасов. Выбор (1867)

Признаться вам, часы летели

И даже дело к у́тру шло,

А было на́ сердце светло.

Н. П. Огарев. Юмор (1840-1841)

Ну, что ж вы там еще? - Идемте!

Идем! Идем!.. Да брось его!

Пускай лежит! Очнется к у́тру!

A. B. Тимофеев. «Вино нам и друг, и спасенье, и грех...» (1834)

Всю ночь - экспресса шум, как шум шагов,

В окне - заиндевелый бор да поле,

К утру́ - вокзал лохматый, сеть проводов,

В сетях - жар-птицы древних колоколен.

С. А. Обрадович. Старый город (1921)

Перепелки к утру́ изнывают во ржах,

Рыбы мечут икру на заре в камышах.

А. П. Платонов. Ночь (1919-1922)

И ночь горит, как старый банный сруб,

Занявшийся от ерунды какой-то,

Насилу побежденная к утру́

Из поданных бессонницей брандспойтов.

Б. Л. Пастернак. Двадцать строф с предисловием (1925)

В сочетании по утру 21 пример, с ударением на корне по ýmpy 9 примеров в начале и в середине строки. Примеры с ударением на окончании по утру́ во всех положениях в строке - в начале, в середине и в конце (возможно, и по́ утру). В частности:

По у́тру сладко дремлет он,

Читая листик Инвалида;

Весь день веселью посвящён,

А в ночь - вновь царствует Киприда.

А. С. Пушкин. К Щербинину (1819) 
Теперь не праздничаем мы, -

Богаты важными трудами,

Не долго спим порою тьмы,

Встаем по у́тру с петухами...

Н. М. Языков. К Вульфу, Тютчеву и Шепелеву (1826)

По утру́ да по началу

Должен быть хорош денёк,

Столько синьки не встречала,

Только слева - огонёк!

А. А. Прокофьев. «Я проснулась - чуть светало...» (1938)

Бывает,

На ней всю ночь он разъезжает

По стойлу; по утру́ придёшь -

Так у бедняжки пот и дрожь.

И. С. Никитин. Городской голова (1859)

Клетку я тогда открою

Ранним-рано по утру́ -

И порхай, господь с тобою,

В крупноягодном бору.

Л. А. Мей. Малиновке (1857)

Характерной особенностью древнерусского языка было ударение на предлогах в предложно-именных сочетаниях. «В дальнейшем процессе развития литературного языка рассматриваемое акцентное явление идет на убыль: сужается круг предлогов, на которые возможна оттяжка ударения, круг слов и форм, с которых она осуществляется» [Воронцова 1979: 136].

Так, на сочетание под вечер в НКРЯ приведено 269 поэтических примеров, из них с ударением на предлоге по́d вечер 57 примеров в начале и в середине строки. Примеры с ударением на существительном под ве́чер во всех положениях в строке - в начале, в середине и в конце (в конце 30 примеров). Кроме того 8 со словами, зависимыми от ве́чер. В частности:

В стойлах усталые кони храпят,

Люди, ночуя, вповалку лежат,

Водка и песни текут спозаранка,

По́д вечер говор, чёт-нечет, орлянка...

К. К. Случевский. В снегах (1860-1878)

Дело по́д вечер, зимой,

И морозец знатный. 
По дороге столбовой

Едет парень молодой, Мужичок обратный...

Н. А. Некрасов. Генерал Топтыгин (1867)

Под ве́чер улицею грязной

Плетется тряский дилижанс.

К. М. Фофанов. В дилижансе (1882)

Забуду ли то время золотое,

Забуду ли блаженный неги час,

Когда, в углу под ве́чер притаясь,

Я призывал и ждал тебя в покое...

А. С. Пушкин. Сон (1816)

И раз пошли под ве́чер

Мы на́ берег крутой,

Смотреть на сини волны,

На запад золотой.

М. Ю. Лермонтов. Тростник (1832)

Здесь в разны игры забавлялась, А тут прекрасных Нимф с полком

Под ве́чер красный собиралась

В прогулку с легким посошком...

Г. Р. Державин. Развалины (1797)

Я поднимусь к лесной сторожке -

И с грустью глянут на меня

Ее подслепые окошки

Под ве́чер сумрачного дня.

И. А. Бунин. «Пустыня, грусть в степных просторах...» (1888)

Не оттого ль, под ве́чер грустных дней, Я полюбил тебя, мой друг прекрасный?

Н. М. Минский. Cum Grano Veneni (1895)

Под ве́чер жизни, в час унылый,

На небо взглянешь впопыхах, И видишь остров сизокрылый На алых, медленных волнах.

С. М. Городещкий. «Под вечер жизни...» (1907) 
В ограде церковной встречает всегдашний

Знакомых деревьев черед круговой,

Но - чудо! — деревья под ве́чер вчерашний

Оделися белой листвой.

А.Д. Скалдин. «Морозное утро...» (1909-1916)

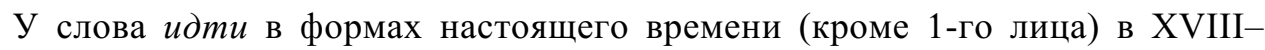
XIX вв. прошел процесс смены ударения с корня на окончание: údemb, údem, и́дем, и́дете, и́дуm > иде́шь, иде́m, иде́м, иде́те / идёшь, идёm, идём, идёте, идým. И та же особенность процесса смены места ударения: при колебании места ударения ударение на окончании чаще встречается в конце стихотворной строки.

Так, по данным НКРЯ, у М.В. Ломоносова отмечено 8 этих форм, из них 3 с ударением на корне (не в конце стихотворной строки) и 5 - на окончании, в частности:

Ведет Творец, Он и́дет вслед;

Воздвиг нас. Россы, ускоряйте

На образ в знак Его побед,

Рифейски горы истощайте...

Ода... императрище Елисавете Петровне, 1761

Покрой твой шлемом верьх, Минерва наших лет,

Воткни копье твое: твой полк готов иде́т...

Венчанная надежда российския империи..., 1742

Тихо и́дут те здесь спящи,

Скоро там текут шумящи,

Мочат злачные ковры.

Ода, которую сочинил господин Франциск де Салиньяк..., 1735

Подобно сей царицы взгляды

Сквозь души и сердца иду́т,

С надеждой смешанны отрады

В объяты страстью мысли льют.

Ода на день брачного сочетания их императорских высочеств..., 1745

У В.К. Тредиаковского 21 такая форма, из них 15 с ударением на корне (1 из них в конце строки) и 6 на окончании.

Где воин и́дет, там успехи;

Моря и реки без помехи...

Императрице Елизавете Петровне.., 1752 
Но вот пропасть статкам нашим всем иде́т, Прямо ж и сюды, сами посмотрите:

Та одна доходы собственны нам жрет. Из комедии «Евнух», 1752

Те и́дут, те ползут, те пресмыкаться знают;

Те плавают в водах, те в воздухе летают... Феоптия. Эпистола III, 1750-1754

Становые жилы от мозгу все врозь иду́т, По своим же трубкам духи жизненны ведут... Феоптия. Эпистола IV, 1750-1754

У В.И. Майкова 18 таких форм, из них 7 с ударением на корне (все не в конце строки) и 11 на окончании. У А.П. Сумарокова 16 таких форм, все с ударением на окончании.

У Г.Р. Державина 71 случай употребления этих форм, которые примерно одинаково распределены по месту в стихотворной строке: 26 в начале строки, 22 в середине строки и 23 в конце строки. Иное распределение в зависимости от места ударения в слове: 19 с ударением на корне, в том числе 5 в начале строки, 13 в середине строки и 1 в конце строки и 52 с ударением на окончании, в том числе 21 в начале строки, 9 в середине строки и 22 в конце строки.

Таким образом, можно видеть, что кроме конца строки выделяется и начало строки, где процесс смены места ударения идет, как и в конце строки, наиболее интенсивно.

У И.А. Крылова 17 таких форм, из них 4 с ударением на корне (все в середине строки) и 13 на окончании (из них 8 в конце строки). У В.А. Жуковского 125 этих форм, из них 6 с ударением на корне (не в конце строки) и 119 на окончании.

У А.С. Пушкина 134 формы, из них 7 с ударением на корне (не в конце строки) и 127 на окончании.

Всё и́дет той же чередой;

Всё так же люди лицемерят,

Всё те же песенки поют,

Клеветникам как прежде верят...

Тень Фон-Визина, 1815

Справят здесь, — лихие гости

Идут от моря. Со злости

Инда плакал царь Дадон,

Инда забывал и сон.

Сказка о золотом петушке, 1834 
Войска и́дут день и ночь;

Им становится невмочь.

Ни побоища, ни стана,

Ни надгробного кургана

Не встречает царь Дадон.

Сказка о золотом петушке, 1834

Идут тесно под скалами.

Вдруг смятение!.. Глядят:

У себя над головами

Красных шапок видят ряд.

Бонапарт и черногоризы [Песни западных славян, 9], 1834

Идут витязи четами,

И блистая сединами

Дядька впереди идет

И ко граду их ведет.

Сказка о ичаре Салтане..., 1831

Но повелитель горделивый

Махнул рукой нетерпеливой:

И все, склонившись, и́дут вон.

Бахчисарайский фонтан, 1821-1823

Раскинув легкие власы,

Как и́дут пленницы младые

Купаться в жаркие часы,

И льются волны ключевые

На их волшебные красы...

Бахчисарайский фонтан, 1821-1823

У М. Ю. Лермонтова 79 таких форм, из них 3 с ударением в корне.

Идут все полки могучи,

Шумны как поток,

Страшно-медленны как тучи,

Прямо на восток.

Cnop, 1841

Вот чей-то голос... Идут на крыльцо...

Параша потянулась и зевнула

Так, что едва не бухнулась со стула...

Сашка: Нравственная поэма, 1839 
Стук карет,

Колясок, дрожек раздается;

На небе стая галок вьется;

Всяк в дом свой завтракать иде́т;

Там тихо ставни растворяют;

И там по улице гуляют

Иль и́дут войско посмотреть

В большую крепость.

Черкесы, 1828

У Н.А. Некрасова 68 этих форм, из них один пример с ударением на корне, остальные с ударением на окончании.

Дождик, что ли собирается,

Ходят по небу бычки,

Вечер пуще надвигается,

Прытче и́дут мужики.

Коробейники, 1861

Процесс переноса ударения с корня на окончание в этих формах закончился в XIX в., норма XX в. - ударение на окончании [Каленчук и др. 2012: 253; Еськова 2015: 275].

Чем можно объяснить, что при колебании места ударения в отмеченных словах прежнее ударение чаще встречается в середине стихотворной строки, а новое ударение - чаще в конце и в начале строки? Обычно конец строки - это и конец фразы, здесь сильная фразовая позиция, а в середине строки середина фразы и слабая фразовая позиция. Сильная фразовая позиция способствует проявлению языкового процесса. Начало стихотворной строки - это обычно и начало фразы, которое привлекает особое внимание говорящих. Таким образом, процесс смены места ударения начинается и протекает в первую очередь в тех местах фразы, в которых внимание говорящих направлено не только на передачу содержания речи, но и на ее формы.

Возможно, при этом играет роль и качество гласных, с которых и на которые переносится ударение. Так, [и] и [э] разной собственной длительности: [и] - гласный верхнего подъема, он короче гласного [э] среднего подъема, который в силу этого и способствует «перетягиванию» на себя ударения, а [и] и [у] - гласные одного подъема, у [у] нет подобных «преимуществ» перед [и]. Этим, возможно, объясняется задержка переноса ударения в форме 3-го лица мн. числа, отмеченная в стихах А.С. Пушкина, М. Ю. Лермонтова и Н. А. Некрасова.

Отмеченная закономерность наблюдается не у всех подобных слов.

Так, например, у слова кати́ться среди примеров XVIII в. встречается кати́mся - 20 примеров, из них 2 в начале строки, 1 в середине, 17 в конце; ка́тится - 5 примеров в середине строки. 
Среди примеров XX в. встречается

кати́тся - 69 примеров, из них 22 в начале строки, 17 в середине, 30 в конце;

ка́тится - 44 примера, из них 4 в начале строки, 35 в середине, 5 в конце.

Таким образом, у этого слова процесс смены места ударения начинается с середины строки.

Очевидно, что могли быть и другие факторы, действующие в процессе. Их еще следует обнаружить и описать.

\section{Литература}

Воронцова В. Л. Русское литературное ударение XVIII-XX вв.: Формы словоизменения. М.: Наука, 1979. 328 с.

Еськова Н.А. Нормы русского литературного языка XVIII-XIX веков. Ударение. Грамматические формы. Варианты слов. Словарь. Пояснительные статьи. М.: Рукописные памятники Древней Руси, 2008. 578 с.

Еськова Н.А., Борунова С.Н., Воронщова В.Л. Орфоэпический словарь русского языка: произношение, ударение, грамматические формы / Под ред. Н. А. Еськовой. M.: ACT, 2014. $1007 \mathrm{c}$.

Каленчук М. Л., Касаткин Л. Л., Касаткина Р. Ф. Большой орфоэпический словарь русского языка. Литературное произношение и ударение начала XXI века: норма и ее варианты. М.: АСТ-Пресс, 2012. 1024 с.

Национальный корпус русского языка [Электронный ресурс]: база данных. Электрон. дан. Режим доступа: http://ruscorpora.ru (свободный). Загл. с экрана.

\section{Leonid L. Kasatkin}

Vinogradov Russian Language Institute of the Russian Academy of Sciences

(Russia, Moscow)

rolekas@yandex.ru

\section{SOME LAWS OF THE PROCESS OF CHANGING THE PLACE OF ACCENT IN THE WORDS OF RUSSIAN LANGUAGE}

Many words of the Russian language now or in the past vary the place of stress in all or in some forms. This variation reflects the process of changing the place of stress in a given word. Poetic works help to see some regularities of this process.

The article discusses the features of the process of changing the stress in the forms of pl. indirect cases of the noun kamen' (the stone), genus. and dates. pl. with prepositions of the noun ' $u$ tro' (the morning), $2^{\text {nd }}$ and $3^{\text {rd }}$ form indicative of the verb 'idti' (to go).

The peculiarity of the process of changing the place of stress is noted that when the place of stress fluctuates, the stress at the end is more often found at the end of the poetic line. In addition, for some examples, the position at the beginning of the line is 
highlighted, where, as at the end of the line, the process of changing the place of stress is the most intense.

These observations suggest that, firstly, the manifestation of the language process is facilitated by a strong phrasal position, because the beginning and the end of the line usually coincide with the beginning and end of the phrase, and they attract special attention of the speakers. In addition, plays a role the quality of vowels from which and to which transferred the stress: a longer vowel (middle or low rise of vowel) contributes to "tug" on the accent with the vowel of the upper level, which is impossible in the case that the vowels in the word form of one level (and the same natural length).

Key words: Russian literary pronunciation, stress, change of place of stress

\section{References}

Es'kova N.A. Normy russkogo literaturnogo yazyka XVIII-XIX vekov. Udarenie. Grammaticheskie formy. Varianty slov. Slovar'. Poyasnitel'nye stat'i [Norms of the Russian literary language of the $18^{\text {th }}-19^{\text {th }}$ centuries. Stress. Grammatical forms. Variants of words. Dictionary. Explanatory articles]. Moscow, Rukopisnye pamyatniki Drevnei Rusi Publ., 2008. 578 p.

Es'kova N. A., Borunova S. N., Vorontsova V. L. Orfoepicheskii slovar' russkogo yazyka: proiznoshenie, udarenie, grammaticheskie formy [Orthoepic dictionary of the Russian language: pronunciation, stress, grammatical forms]. Ed. N.A. Es'kova. Moscow, AST Publ., 2014. 1007 p.

Kalenchuk M.L., Kasatkin L.L., Kasatkina R.F. Bol'shoi orfoepicheskii slovar' russkogo yazyka. [A comprehensive pronouncing dictionary of Russian]. Moscow, ASTPress Publ., 2012. 1024 p.

Russian National Corpus. Available at: http://ruscorpora.ru

Vorontsova V.L. Russkoe literaturnoe udarenie XVIII-XX vv.: Formy slovoizmeneniya [Russian literary accent $18^{\text {th }}-20^{\text {th }}$ centuries: Forms of change]. Moscow, Nauka Publ., 1979. 328 p. 